\title{
Relacje zewnętrze Unii Europejskiej w dziedzinie kultury. Slabości polityki
}

Sektor kultury aspiruje dziś do ważnej roli w stosunkach międzynarodowych Unii Europejskiej, jednakże dysponuje ograniczonymi możliwościami formalno-instytucjonalnymi. Polityka kulturalna Unii Europejskiej powiększająca z biegiem czasu zasięg oddziaływania o wymiar pozaeuropejski, dziś sytuuje się na dwóch filarach: wewnętrznym i zewnętrznym. Niniejszy artykuł jest próbą prześledzenia rozbieżności (wraz z ich konsekwencjami) występujących między deklaratywnym charakterem relacji zewnętrznych Unii Europejskiej w sektorze kultury a realnymi kompetencjami organów UE odpowiedzialnymi za prowadzenie zagranicznej polityki kulturalnej UE. Jest próbą analizy dychotomii definiowanej między partykularnym rozumieniem dyplomacji kulturalnej a globalnym podejściem do wykorzystania soft power w XXI wieku. Problem kulturalnych relacji zewnętrznych UE polega na tym, iż proces decyzyjny instytucji unijnych wstrzymuje oddziaływanie kulturowo-cywilizacyjne Europy.

Zasadniczym celem rozważań jest prześledzenie i ocena zmian w priorytetach polityki kulturalnej UE, jakie zachodziły na przestrzeni lat; wskazanie mechanizmów rozszerzających wpływy kultury, scharakteryzowanie natury tychże rozszerzeń, a także ich skutków politycznych. W artykule weryfikowane są trzy hipotezy badawcze: 1) dziedzina kultury była stopniowo i efektywnie włączana przez Komisję Europejską i Wysokiego Przedstawiciela Unii do spraw zagranicznych i polityki bezpieczeństwa (WP) do relacji zewnętrznych jako tzw. miękka siła; 2) działania zewnętrzne w dziedzinie kultury nie mają szans wejść w fazę dojrzałą, ponieważ posiadają ograniczenia formalne; 3) UE i państwa członkowskie nie osiągnęły konsensusu w obszarze promocji kultury na zewnątrz UE, dlatego działania zewnętrzne UE w dziedzinie kultury są postrzegane jako enigmatyczne, jeśli chodzi o skutki polityczne.

Artykuł został oparty na analizach jakościowych, czyli zawartości treści dokumentów oraz potencjału systemu instytucjonalnego UE. Ramy czasowe przedstawianego dyskursu to okres od 2005 do 2020 r. Artykuł składa się z dwóch części. Pierwszą stanowią rozważania dotyczące założeń ideowych i priorytetów polityki kulturalnej UE w stosunku do państw trzecich w latach 2005-2020, kształtujących podstawy programów i działań Europejskiej Służby Działań Zewnętrznych (WSDZ) w sektorze kultury. W drugiej części tekstu znajduje się omówienie zasad funkcjonowania ESDZ z naciskiem na kompetencje w dziedzinie kultury oraz ocenę starań WP w kierunku strategizacji kultury. Całość zamyka podsumowanie weryfikujące hipotezy badawcze. 


\section{Kultura w stosunkach międzynarodowych UE: Konwencja UNESCO (2005), Agenda kultury (2007)}

Istotną zmianę $\mathrm{w}$ procesie wprowadzania kultury do zagadnień polityki zewnętrznej UE odegrały w pierwszej dekadzie XX w. dwa dokumenty: Konwencja UNESCO w sprawie ochrony i promowania różnorodności form wyrazu kulturowego z 2005 r. (Konwencja UNESCO, 2005) oraz Europejska Agenda ds. kultury z 2007 r. (KE: Europejska agenda, 2007). Było to w okresie, w którym nie ukonstytuowała się jeszcze Europejska Służba Działań Zewnętrznych (ESDZ), czyli de facto nie podjęto istotnych działań z zakresu dyplomacji kulturalnej. Konwencja UNESCO w sprawie ochrony i promowania różnorodności form wyrazu kulturowego była pierwszym dokumentem UNESCO podpisanym przez Komisję Europejską w imieniu państw członkowskich, do czego upoważniła ją Rada Europejska w listopadzie 2004 r. Dokument zachęcał do popierania idei różnorodności kulturowej na świecie oraz kształtowania polityk publicznych przyczyniających się do jej wzmacniania. Artykuł 4 Konwencji precyzował najważniejsze definicje, czyli „różnorodność kulturową”, „treści kulturowe, „formy wyrazu kulturowego”, „działalność, dobra i usługi kulturalne”, „przemysły kultury”, „ochronę” i „międzykulturowość”. Konwencja podkreślała konieczność zaakceptowania przez państwa UE idei wielości/rozmaitości form, przez które twórcy przekazują artystyczną ekspresję. Zalecała, aby państwa - programując narodowe polityki kulturalne - wprowadzały do działań koncept „różnorodności form wyrazu”. „Międzykulturowość” zgodnie z art. 4 ust. 8 Konwencji definiowano jako „... występowanie różnych kultur i równoważnych interakcji między nimi”. Powyższe idee miały podlegać ochronie i promocji. Ratyfikowanie Konwencji przez UE pozwalało Unii na redefiniowanie priorytetów w relacjach wobec państw trzecich. Istotne było zachowanie równowagi $\mathrm{w}$ trosce o ochronę głównych idei między państwami rozwiniętymi a rozwijającymi się. Artykuł 12 Konwencji dookreślał kwestie współpracy międzynarodowej. Temu służyć miał dialog między stronami przy wzmocnieniu roli instytucji publicznych zdolnych do wyznaczania strategicznych celów oraz organizacji sektora non-profit będącymi podmiotami społeczeństwa obywatelskiego.

Konwencja UNESCO broniła pluralizmu kulturowego jako aksjomatu współczesnej polityki kulturalnej. Podkreślała możliwość „stworzenia jednostce wyboru form wyrazu kulturowego", na co wskazywał art. 2 ust. 1 Konwencji, a co podkreślała Europejska Konwencja Praw Człowieka i Podstawowych Wolności (EKPCZ) Rady Europy (Bieczyński, 2011). Konwencja zwracała uwagę na demokrację kulturalną i równość. Wymowę równościową Konwencji dostrzegł raport z jej wdrożenia przygotowany przez Dyrekcję Generalną ds. Polityk Wewnętrznych Unii (Ratajski, 2014). Wskazywał on na zależność zachodzącą pomiędzy państwem demokratycznym a problematyką promowania różnych form wyrazu kulturowego. Raport podkreślał, że w państwach, których władza rozumie i przestrzega prawa jednostki i wolności twórczej może realizować się w pełni idea pluralizmu kulturowego. Dokument dostrzegał możliwość propagowania różnorodności kulturowej poprzez działania zewnętrzne UE. Ich celem byłoby „...udoskonalanie »integracji świato- 
wej«, aby zapewnić pokój i ochronę socjalną jako swoiste egzystencjalne dopełnienie globalizacji o charakterze wyłącznie gospodarczym" (ibidem).

Europejska Agenda kultury w dobie globalizacji (KE: Europejska agenda) czyli pierwszy dokument strategiczny UE w dziedzinie kultury, przedstawiony przez Komisję Europejską 10 maja 2007 r. włączyła propagowanie kultury do dziedziny stosunków międzynarodowych Unii. Cele strategicznie Agendy dzieliły się na: 1) promocję różnorodności kulturowej i dialogu międzykulturowego; 2) propagowanie kultury jako katalizatora kreatywności w ramach strategii lizbońskiej oraz na rzecz wzrostu gospodarczego i zatrudnienia; 3) propagowanie kultury jako istotnego elementu stosunków międzynarodowych UE. Priorytet 3 Kultura jako istotny element $w$ stosunkach międzynarodowych odnosił się do stosunkowo nierozpoznanego jeszcze obszaru interwencji UE w dziedzinie kultury. Komisja zauważała potencjał soft power. Uznając kulturę za depozytariusza wartości i norm europejskich (godność ludzka, solidarność, tolerancja, wolność słowa, poszanowanie różnorodności i dialogu międzykulturowego), dostrzeżono jej wartość promocyjną. Dotychczasowa polityka zewnętrzna w dziedzinie kultury - oceniona pozytywnie - skupiała się w dużej mierze na ochronie dziedzictwa kulturowego i dialogu międzykulturowym $^{1}$ (Decyzja nr 1983/2006/WE, 2006) jako narzędziach utrzymywania pokoju. Działania w tych obszarach skutkowały utworzeniem Fundacji im. A. Lindth w Aleksandrii oraz zbliżeniem UE z państwami bałkańskimi. W Agendzie wskazano na konieczność działań zintegrowanych, tak w UE, jak i poza nią, przy czym głównym pomostem zintegrowanych aktywności miało być wzmocnienie „dialogu międzykulturowego ze wszystkimi krajami i regionami, poprzez wykorzystanie np. więzów językowych Europy z wieloma krajami” (KE: Europejska agenda). Zatem Dialog rozumiano szeroko. Promując kulturę europejską w państwie partnerskim, należało równocześnie promować kulturę państwa partnerskiego w Europie. Relacje zewnętrzne UE miały przebiegać dwutorowo: Komisja zapewniła o systematycznym włączaniu kultury do polityk zewnętrznych w celu większej widoczności i skuteczności sektora kultury w działaniach dyplomatycznych UE; a także - postanowiła wspierać konkretne wydarzenia artystyczne jako element polityki rozwoju. Aby dodatkowo podkreślić wagę działań zewnętrznych UE w sektorze kultury, priorytet 3 rozpisano na 5 zadań szczegółowych, wśród których do najważniejszych należały: ułatwianie dostępu do rynku europejskiego dla produktów z krajów rozwijających się, promowanie różnorodności form wyrazu kulturowego na świecie z uwzględnieniem kultury lokalnej; propagowanie aktywnego udziału UE w pracach organizacji międzynarodowych zajmujących się kulturą i w ramach procesu „Sojuszu Cywilizacji” ONZ².

Propozycje Komisji Europejskiej zawarte w Agendzie zostały zaakceptowane przez Parlament Europejski (Rezolucja PE, 2008), Radę (Rezolucja Rady, 2007) i Komitet Regionów (Opinia Komitetu Regionów, 2008). Rezolucja Parlamentu Europejskiego podkreślała dialog jako instrument współpracy międzynarodowej, rozwijanie kompetencji międzykulturowych i wielojęzykowych. Istotnym wąt-

${ }^{1}$ Rok 2008 został ogłoszony „Europejskim Rokiem Dialogu Międzykulturowego”.

${ }^{2}$ Konsekwencją niektórych zapisów Agendy były protokoły do umów handlowych podejmujące aspekty kulturalne. 
kiem był postulat włączenia kultury i stosunków międzynarodowych w kulturze do europejskiej polityki rozwoju. Komitet Regionów, opiniując europejską Agendę ds. kultury, podkreślił jej możliwy wpływ na politykę regionalną w Europie, przypominając o istotnej roli samorządów terytorialnych w promocji dziedzictwa kulturowego oraz innowacji artystycznych. Zgodnie z postanowieniami odnowionej strategii lizbońskiej, europejskie regiony zobowiązane były do prac na rzecz wzmocnienia turystyki, której nieodzownym instrumentem jest promocja bogactwa kultur.

Przyjęcie Europejskiej Agendy ds. kultury i jej realizacja było krokiem milowym w transformacji założeń polityki kulturalnej UE. Dzięki wdrożeniu Agendy, kultura zyskała miejsce pełnoprawnej polityki unijnej, kompatybilnej z ważnymi aktami normatywnymi UE. Oprócz regularnie ogłaszanych i prowadzonych programów wspólnotowych na rzecz kultury, zyskała nowy obszar aktywności, którym były relacje zewnętrzne. Pozycjonowanie kultury w stosunkach międzynarodowych zostało potwierdzone w Sprawozdaniu Komisji do Parlamentu Europejskiego, Rady Europejskiej, Komitetu Ekonomiczno-Społecznego i Komitetu Regionów w sprawie wdrożenia Europejskiej Agendy Kultury (Sprawozdanie Komisji, 2010). Sprawozdanie monitorowało implementację założeń Agendy, analizując zastosowanie trzech najważniejszych jej priorytetów w praktyce. I tak jeśli chodzi o cel 3, Komisja wydzieliła dwa obszary promocji kultury w polityce zagranicznej UE. Należały do nich: Europejska Polityka Sąsiedztwa (ENP) oraz polityka rozwoju względem krajów trzecich. W ramach polityki sąsiedztwa wyszczególniono Unię dla Sródziemnomorza oraz program kulturalny Partnerstwa Wschodniego, który ostatecznie zastał zainicjowany w $2011 \mathrm{r}$. W ramach polityki rozwoju, Komisja zwróciła uwagę na współpracę kulturalną UE z państwami AKP oraz w obrębie funduszy strukturalnych.

\section{Testowanie stosunków międzynarodowych UE w sektorze kultury}

Dalsze plany w relacjach zewnętrznych UE w sektorze kultury Komisja Europejska oparła o wyniki badań empirycznych. Były one zebrane w ekspertyzie Preparatory Action (Preparatory Action, 2014) przygotowanej pod kierunkiem hinduskiego badacza i byłego eksperta UNESCO Yudhishthira Raja Isara. Raport został opublikowany i udostępniony w 2014 r. Badanie, obejmujące 54 państwa pozaunijne i 16 państw sąsiedzkich UE, było możliwe dzięki Rezolucji Parlamentu Europejskiego z dnia 12 maja 2011 r. (Rezolucja PE, 2011) w sprawie kulturowego wymiaru działań zewnętrznych UE, która uruchomiła środki grantowe przeznaczone na ten cel. Badanie polegało na rozeznaniu możliwości współpracy UE z państwami Azji (Japonia, Korea Pd., Chiny), krajami arabskimi (Algieria, Jordania, Liban), kaukaskimi (Armenia, Azerbejdżan), Rosją, Ukrainą i USA w dziedzinie kultury, biorąc pod uwagę lokalne plany rozwojowe, a także współpracę regionalną. Raport dostarczył szereg konkluzji. Wskazywały one na wolę współpracy badanych państw z UE, zwłaszcza w zakresie możliwości 
tworzenia nowych miejsc pracy w przemysłach kreatywnych. Dnia 10 czerwca 2014 r. Komisja Europejska wydała często cytowany Komunikat prasowy $D y$ plomacja kulturalna UE potrzebuje nowego impulsu (KE: Komunikat prasowy, 2014) komentujący konkluzje ww. raportu. Ówczesna Komisarz UE ds. edukacji, kultury, wielojęzyczności i młodzieży Androulla Vasiliou użyła w Komunikacie terminu „dyplomacja kulturalna” wskazując na konieczność uruchomienia procedur dyplomatycznych w kulturze, które miałaby zastąpić współpracę międzyinstytucjonalną. Uznała kulturę za ważny „towar” eksportowy UE ze względu na pielęgnowanie wartości europejskich, ale także wykorzystania jej potencjału ekonomicznego. Komunikat KE definiował unijne obszary działania w zakresie „dyplomacji kulturalnej”. Należały do nich m.in. możliwość tworzenia attachatów kulturalnych przy delegaturach UE, nowe metody finansowania kultury, współpraca międzynarodowa w sektorze kultury za pośrednictwem instytutów kultury państw członkowskich UE, usuwanie barier w mobilności artystów, wykorzystywanie potencjału kultury $w$ miastach, zachęcanie młodych ludzi do tworzenia projektów kulturalnych i - co być może najważniejsze - monitorowanie i ocena projektów oraz strategii dyplomacji kulturalnej.

Właściwie od Komunikatu KE z czerwca 2014 r. coraz wyraźniej politycy UE mówili o „dyplomacji kulturalnej”, choć oficjalne dokumenty unijne pozostały przy terminologii „działań zewnętrznych w kulturze”. To świadczyło o dystansowaniu się instytucji od prowadzenia dyplomacji kulturalnej per se i trzymania się litery traktatów, ponadto - dowodziło niejednoznaczności stanowisk politycznych. Na przykład Konkluzje Rady z dnia 24 listopada 2015 r. w sprawie kultury w stosunkach zewnętrznych UE ze szczególnym uwzględnieniem kultury we współpracy na rzecz rozwoju (Konkluzje Rady, 2015) proponowały działania w dwóch zakresach: w ramach stosunków zewnętrznych UE oraz w ramach współpracy na rzecz rozwoju. W ramach stosunków zewnętrznych Rada podkreślała odświeżenie dialogu wielokulturowego oraz konieczność strategicznego podejścia do kultury, polegającego na systematycznym włączaniu tego sektora w ,priorytety tematyczne i geograficzne, realistyczne cele i wyniki, grupy docelowe, wspólne interesy i inicjatywy, przepisy dotyczące finansowania" (ibidem). Strategiczne podejście miało na celu włączanie kultury w działania antykryzysowe (np. kryzys imigracyjny), zwalczanie postaw ksenofobicznych czy przeciwdziałanie niszczeniu dziedzictwa kulturowego w państwach poza UE. W ramach współpracy na rzecz rozwoju, Rada postulowała uznanie kultury jako czynnika prorozwojowego. Konkluzje podkreślały soft power kultury jako siły wspomagającej działania pokojowe na terenach ogarniętych konfliktami lub pokonfliktowych, dziedziny wolności wypowiedzi, stymulującej aktywne postawy obywatelskie i przemiany demokratyczne. Rezolucja wzywała do spotkań roboczych wypracowujących zadania dla kultury w ramach długofalowej strategii rozwoju UE, a także wzywała Komisję Europejską wraz z WP do opracowania i przedstawienia Radzie konkretnego planu włączenia kultury do strategii rozwojowych UE. W Konkluzjach Rady z dnia 15 czerwca 2017 r. w sprawie strategicznego podejścia UE do międzynarodowych stosunków kulturalnych (Konkluzje Rady, 2017) uznano rolę kultury w stosunkach międzynarodowych UE w takich dziedzinach jak: zwalczanie terroryzmu, odporność społeczeństw i rozwiązywanie konfliktów. 


\section{W stronę strategii EU w dziedzinie międzynarodowych stosunków kulturalnych (2016)}

W listopadzie 2015 r. Rada zwróciła się oficjalnie do Komisji oraz WP o opracowanie strategicznego podejścia do kultury w relacjach zewnętrznych UE i w dyplomacji publicznej UE. W ślad za tym WP zdecydował o ogłoszeniu wspólnego Komunikatu do Parlamentu Europejskiego i Rady $W$ stronę strategii UE $w$ dziedzinie międzynarodowych stosunków kulturalnych. Komunikat został ogłoszony 8 czerwca 2016 r. (Wspólny Komunikat, 2016). Przyjęto nazywać ten dokument „strategią”.

UE zamierzała dzięki kulturze wzmocnić swoją pozycję na arenie międzynarodowej. Uznano, że istotą działań unijnych w dziedzinie kultury będzie nadal promowanie różnorodności kulturowej i poszanowania praw człowieka oraz wzajemnego szacunku, a także dialogu międzykulturowego; przestrzeganie zasad komplementarności i pomocniczości oraz promowanie podejścia przekrojowego do kultury. UE podtrzymywała tym samym sprawdzone metody soft power. W celu promowania powyższych idei, wskazała: Instrumenty Partnerstwa, Europejski Instrument na rzecz Wspierania Demokracji i Praw Człowieka (Rozporządzenie PE i Rady nr 235/2014, 2014), Instrument na rzecz przyczyniania się do Stabilności i Pokoju (Rozporządzenie PE i Rady nr 230/2014, 2014), program Kreatywna Europa (Rozporządzenie PE i Rady, 2013) oraz funkcjonujące geograficzne ramy współpracy: Politykę Rozszerzania (PR), EPS oraz Umowy o Partnerstwie AKP-UE. W ramach Polityki Rozszerzenia, istniejącymi instrumentami pomocy państwom Europy Południowo-Wschodniej w zakresie kultury były: Instrumenty Pomocy Przedakcesyjnej (IPA), Instrumenty wynikające z procesu lublańskiego I i II w zakresie dziedzictwa kulturowego oraz wsparcie w ramach programu „Kreatywna Europa”. Wszystkie proponowane instrumenty pomocowe zostały zawarte w poniższej tabelce wraz z przypisanymi im obszarami geograficznymi.

Tabela 1

Programy i instrumenty UE wykorzystywane w relacjach zewnętrznych

\begin{tabular}{|c|c|c|c|c|}
\hline $\begin{array}{l}\text { Geograficzne } \\
\text { ramy wspólpracy } \\
\text { kulturalnej UE }\end{array}$ & $\begin{array}{l}\text { Charakterystyka } \\
\text { programów }\end{array}$ & Specyfika & Państwa & $\begin{array}{l}\text { Instrumenty } \\
\text { wsparcia }\end{array}$ \\
\hline 1 & 2 & 3 & 4 & 5 \\
\hline \multirow[t]{3}{*}{$\begin{array}{l}\text { Polityka Rozsze- } \\
\text { rzenia UE (PR) }\end{array}$} & & $\begin{array}{l}\text { Pomoc państwom } \\
\text { bałkańskim i Bał- } \\
\text { kanów Zachodnich. }\end{array}$ & $\begin{array}{l}\text { Albania, Bośnia } \\
\text { i Hercegowina, } \\
\text { Północna Mace- } \\
\text { donia, Kosowo, } \\
\text { Czarnogóra } \\
\text { i Serbia. }\end{array}$ & $\begin{array}{l}\text { Instrumenty Po- } \\
\text { mocy Przedakce- } \\
\text { syjnej (IPA). }\end{array}$ \\
\hline & $\begin{array}{l}\text { Proces lublański I } \\
\text { Proces lublański II }\end{array}$ & $\begin{array}{l}\text { Wsparcie i ochrona } \\
\text { europejskiego dzie- } \\
\text { dzictwa kulturowe- } \\
\text { go państw Europy } \\
\text { pd-zach. }\end{array}$ & & \\
\hline & $\begin{array}{l}\text { Program Kreatywna Eu- } \\
\text { ropa }(2014-2020)\end{array}$ & $\begin{array}{l}\text { Interdyscyplinarne } \\
\text { działania na rzecz } \\
\text { kultury i dziedzic- } \\
\text { twa. }\end{array}$ & & \\
\hline
\end{tabular}




\begin{tabular}{|c|c|c|c|c|}
\hline 1 & 2 & 3 & 4 & 5 \\
\hline \multirow[t]{2}{*}{$\begin{array}{l}\text { Europejska Poli- } \\
\text { tyka Sąsiedztwa } \\
\text { (EPS) } \\
16 \text { państw }\end{array}$} & $\begin{array}{l}\text { Inicjatywami na rzecz } \\
\text { współpracy regionalnej } \\
\text { w regionie Morza Śród- } \\
\text { ziemnego, } \\
\text { Proces barceloński, } \\
\text { Meda. }\end{array}$ & $\begin{array}{l}\text { Ochrona dziedzic- } \\
\text { twa, polityka audio- } \\
\text { wizualna, umowy } \\
\text { bilateralne. }\end{array}$ & $\begin{array}{l}\text { Algieria, Egipt, } \\
\text { Izrael, Jordania, } \\
\text { Liban, Libia, } \\
\text { Maroko, Pale- } \\
\text { styna, Syria oraz } \\
\text { Tunezja. }\end{array}$ & \begin{tabular}{|l|} 
Europejski Instru- \\
ment Sąsiedztwa \\
$(2014-2017)$ \\
-17 mln euro \\
na wspieranie \\
mediów, kultury \\
oraz rozwój \\
regionu Morza \\
Śródziemnego.
\end{tabular} \\
\hline & Partnerstwo Wschodnie. & $\begin{array}{l}\text { Platforma 4 PW: } \\
\text { edukacja i kultura. }\end{array}$ & $\begin{array}{l}\text { Armenia, Azer- } \\
\text { bejdżan, Białoruś, } \\
\text { Gruzja, Mołdawia } \\
\text { oraz Ukraina. }\end{array}$ & \\
\hline $\begin{array}{l}\text { Wspólpraca na } \\
\text { rzecz rozwoju }\end{array}$ & $\begin{array}{l}\text { 1. Programy geograficz- } \\
\text { ne: } 47 \text { państw rozwi- } \\
\text { jających się (Ameryce } \\
\text { Lacińska, Azja Połu- } \\
\text { dniowa, Południowo- } \\
\text {-Wschodnia i Środkowa, } \\
\text { Bliski Wschód, Afryka } \\
\text { Południowa; } \\
\text { 2. Program panafrykański. }\end{array}$ & & & $\begin{array}{l}\text { Instrument } \\
\text { Finansowania } \\
\text { Współpracy na } \\
\text { rzecz } \\
\text { Rozwoju. }\end{array}$ \\
\hline $\begin{array}{l}\text { Umowa o part- } \\
\text { nerstwie AKP-UE } \\
\text { (2000) }\end{array}$ & Program Kultury AKP+. & & & $\begin{array}{l}\text { Europejski } \\
\text { Fundusz Rozwoju } \\
\text { (EFR). }\end{array}$ \\
\hline
\end{tabular}

Źródło: Opracowanie własne na podstawie KE: Wysoki Przedstawiciel Unii do spraw zagranicznych i polityki bezpieczeństwa. Wspólny Komunikat do Parlamentu Europejskiego i Rady, W stronę strategii UE w dziedzinie międzynarodowych stosunków kulturalnych, JOIN (2016) 29 final. Bruksela, 8.06.2016.

Strategia proponowała 3 zasadnicze cele działania, zmierzające do poprawy stosunków międzynarodowych w oparciu o nowe zasady dyplomacji kulturalnej. Należały do nich: 1) wspieranie kultury jako siły napędowej zrównoważonego rozwoju społecznego i gospodarczego; 2) promowanie kultury i dialogu międzykulturowego w pokojowych stosunkach między społecznościami; 3) zacieśnianie współpracy w zakresie dziedzictwa kulturowego. Wymienione Cele, choć pozornie przypominały cele agendy z 2008 r. posiadały rozbudowane, wielopiętrowe i skomplikowane zadania szczegółowe. Na przykład Cel nr 1 odnosił się do wsparcia dla „Europejskich Stolic Kultury" (rozwój miast poprzez kulturę) oraz rozwoju partnerstw miast europejskich z miastami Ameryki Łacińskiej oraz budowania strategii w miastach historycznych. Ważny był rozwój mediów - współpraca z państwami Afryki Północnej w ramach programu Med. Culture (2014-2018) oraz programu dla filmowców MedFilm. Duże wsparcie przewidywano dla sektora kreatywnego (program „Kreatywna Europa”), w tym nowych modeli biznesowych i strategii eksportowych. Proponowano wspieranie sieci, centrów kreatywnych i klastrów na terenie Azji (małe i średnie przedsiębiorstwa w Korei Pd.).

Postawienie w Celu nr 2 na propagowanie dialogu międzykulturowego w pokojowych stosunkach między społecznościami też nie było nowością. Dialog międzykulturowy miał być tym razem promowany poprzez projekty międzynarodowej współpracy, 
dofinansowane w ramach „Kreatywnej Europy”, Partnerstwa Wschodniego, w oparciu o struktury działalności Fundacji im. Anny Lindh oraz poprzez Instrument na rzecz Przyczyniania się do Stabilności i Pokoju. Zalecano szkolenia dla obserwatorów międzynarodowych misji i wyborów (tu drażliwe kwestie kulturowe i etniczne), wspieranie praw kulturalnych (zgodnie z Międzynarodowym paktem praw gospodarczych, społecznych i kulturalnych, w tym praw ludności tubylczej określonych w przyjętej przez ONZ Deklaracji praw ludów tubylczych (UNDRIP)). Realizacja celu nr 3 odnoszącego się do ochrony dziedzictwa kulturowego miała opierać się o bazy informacyjne, pozwalające na inwentaryzację dzieł zrabowanych; dane dotyczące zakazu nielegalnego handlu artefaktami sztuki, grabieży wojennych, systemu certyfikacji przywozu dóbr kultury do UE itp.

Istotną częścią Strategii z 2016 r. były postulaty dotyczące wprost dyplomacji kulturalnej. Opierając się na raportach i dokumentach unijnych uznano, że w dyplomacji kulturalnej musi zachodzić spójność między działaniami państw członkowskich i ich służbą dyplomatyczną, samorządami a instytucjami unijnymi. W związku z tym wyróżniono 2 cele dyplomatyczne: 1) zacieśnioną współpracę w UE; 2) wymianę międzykulturową studentów, badaczy i absolwentów. Podstawą współpracy miały być zasoby państw członkowskich UE: instytucje kultury państw członkowskich, ambasady i konsulaty oraz Stowarzyszenie Narodowych Instytutów Kultury Unii Europejskiej (European Union National Institutes for Culture, EUNIC). Uznano, że należy wzmocnić rolę Delegatur UE zakładając w nich punkty kontaktowe ds. kultury. Komisja miała zaproponować nowy rodzaj współpracy pomiędzy ESDZ, instytutami kultury państw członkowskich oraz ich organizacjami patronackimi (w ramach ich uprawień), wyznaczający zasady współpracy paneuropejskiej. Ważnym konceptem programowym było powołanie do życia „Europejskich Domów Kultury” w państwach trzecich w koalicji z instytutami kultury państw członkowskich znajdującymi się na terytorium danego państwa. Kluczową kwestią były wspólne imprezy kulturalne. W Strategii zdecydowano również o utworzeniu w 2016 r. internetowej Platformy dyplomacji kulturalnej.

Dnia 23 maja 2017 r. Rada akceptując Wspólny Komunikat KE ogłosiła Konkluzje w sprawie strategicznego podejścia UE do międzynarodowych stosunków kulturalnych (Konkluzje Rady, 2017). Rekomendowała państwom członkowskim ściślejszą współpracę z odpowiednimi ministerstwami oraz władzami lokalnymi w kwestii wsparcia działań zewnętrznych UE, zaś KE - nadanie priorytetu inicjatywom kulturalnym na forum międzynarodowym przy użyciu istniejących polityk unijnych, ESDZ (utworzenie Grupy Przyjaciół Prezydencji), wzmożenie działań Platformy dyplomacji kulturalnej UE. Rekomendowano również inicjatywę programów pilotażowych we współpracy z organizacjami pozarządowymi, klastrami EUNIC oraz Delegaturami UE.

\section{Nowy europejski program na rzecz kultury (2018)}

Nowy europejski program na rzecz kultury, przedstawiony przez Komisję Europejską w jej Komunikacie do PE, Rady i Komitetu Społeczno-Ekonomicznego i Komitetu Regionów 22 maja 2018 r. (Komunikat Komisji, 2018) zakładał 3 cele strategiczne: 
1) wymiar społeczny - wykorzystanie wagi kultury i różnorodności kulturowej do celów spójności społecznej i dobrostanu; 2) wymiar gospodarczy - wspieranie kreatywności opartej na kulturze w obszarze edukacji i innowacji oraz w zakresie miejsc pracy i wzrostu gospodarczego; 3) wymiar zewnętrzny - wzmacnianie międzynarodowych stosunków kulturalnych.

Kluczowym zagadnieniem programu (tzw. nowej Agendy w kulturze) rzutującym na całościowy jego sens było budowanie „zdolności kulturowej”, czyli specyficznych możliwości/umiejętności sektora kultury definiowanych jako „...zapewnienie dostępu do szerokiej gamy jakościowych wydarzeń kulturalnych, propagowanie możliwości uczestnictwa i tworzenia dla wszystkich oraz wzmacnianie powiązań między kulturą i edukacją, sprawami społecznymi, polityką miejską, badaniami naukowymi i innowacjami” (Komunikat Komisji, 2018). Zdolność kulturowa danej społeczności rodzi się w powiązaniu kultury z różnymi, pokrewnymi mniej lub bardziej sektorami, jest generowana z uczestnictwa w kulturze i wpływa, jak podaje Agenda, ,pozytywnie na stan zdrowia i dobrostan” obywateli. Dodatkowo „zdolność kulturowa” rodzi się z obcowania z dziedzictwem kulturowym, które stawało się priorytetem polityki kulturalnej UE. Wszystkie wymienione wyżej cele miały zostać wzmocnione celami Programów „Erasmus+”, „Kreatywnej Europy”, a w niej nowe działanie na 2018 r. - „Kulturalne i twórcze przestrzenie i miasta”. „Zdolność kulturowa” jest pojęciem zaczerpniętym z najnowszych badań brytyjskiego rynku kultury i sztuki (Gross, Wilson, Bull, 2017). Empirycznie sprawdzona jako żywo funkcjonująca w społeczeństwach wysoko rozwiniętych, przeniknęła do terminologii unijnej, stając się użyteczną dla celów politycznych, bowiem w niekonwencjonalny sposób określającą potencjał ludzi do współtworzenia. Wskazywała na łączenie w demokratycznym akcie twórczym: sztuki, branż kreatywnych oraz kreatywności każdego pojedynczego człowieka. Uchodzi za nowy, współczesny aspekt demokracji kulturalnej, rozumianej nie - jak dotychczas - jako możliwość dostępu i prezentacji wszelkiego typu sztuk, ale jako swobodne współtworzenie kultury czy wezwanie do współpracy kulturalnej w celu promowania trwałych i różnorodnych możliwości tworzenia kultury tak w danym państwie, jak i poza nim.

Trzeci cel agendy Wymiar zewnętrzny - wzmacnianie międzynarodowych stosunków kulturalnych był znacznie bardziej rozbudowany w stosunku do treści Agendy z 2007 r. Zawierał trzy wymiary: zrównoważony rozwój, dialog międzykulturowy oraz ochronę dziedzictwa kulturowego. Przede wszystkim powtórzono tu rolę kultury jako stymulatora pokojowych stosunków zewnętrznych pomiędzy UE a partnerami zagranicznymi oraz stabilizatora napięć politycznych. Zwrócono uwagę na rolę kultury jako nośnika tożsamości europejskiej i spójności. Obszarowi stosunków zewnętrznych nadano konkretne zadania na przyszłość. Postanowiono wzmacniać Partnerstwo Wschodnie, współpracę regionalną z państwami Bliskiego Wschodu, Afryką Północną i Ameryką Łacińską oraz zintensyfikować pomoc na rynku pracy i zatrudnienia w państwach AKP (poprzez dostęp tych państw do Europejskiego Funduszu Rozwoju). Jako nowość zaplanowano rozwój współpracy z Chinami i Japonią, uwidoczniony m.in. w nadzorze nad Dziedzictwem Jedwabnego Szlaku w Azji Środkowej, Afganistanie i Iranie. Osobnym zagadnieniem było wzmocnienie współpracy z państwami Bałkan

${ }^{3}$ Cultural capacity, specyficzny termin angielski, pojęcie odnoszące się do zdolności, możliwości, tworzenia potencjału, generowaniu siły i umiejętności. 
Zachodnich, które brały aktywny udział w obchodach „Europejskiego Roku Dziedzictwa Kulturowego" (2018). Liczono na znaczny wzrost świadomości dziedzictwa europejskiego wśród obywateli UE oraz na możliwość wypracowania dobrych praktyk na przyszłość w szczególności rozwiązań przeciwdziałających degradacji obszarów zabytkowych.

\section{Rola Wysokiego Przedstawiciela Unii w budowaniu zewnętrznych relacji kulturalnych $\mathrm{UE}$}

Omówione wyżej niewiążące unijne akty prawne są dowodem rozwijania polityki zagranicznej UE w dziedzinie kultury. Idąc od postulatów różnorodności kulturowej i ochrony form wyrazu artystycznego Unia definiowała swoją rolę jako propagatora dialogu międzykulturowego i obrońcy praw człowieka (w tym wolności słowa). W drugiej dekadzie XXI w. wprowadzono do języka unijnych przepisów pojęcie „dyplomacji kulturalnej”, podkreślając zarazem możliwości uruchomienia procedur dyplomatycznych w miejsce współpracy międzyinstytucjonalnej. Kultura jako „towar eksportowy" UE miała być wykorzystywana w celach pokojowych, stabilizacyjnych oraz demokratyzujących państwa sąsiedzkie i partnerskie. Miała stać się zintegrowaną częścią europejskich polityk: sąsiedztwa, rozszerzenia i rozwoju. Zewnętrzne działania UE w zakresie kultury prowadziły globalnie do wygenerowania pomiędzy UE a jej partnerami „zdolności kulturowej” pozwalającej na wielopłaszczyznowe współdziałanie i współrozumienie, a także zbudowanie odporności obywatelskiej. Strategia 2016 r. zalecała konkretne rozwiązania instytucjonalne, świadczące o rozwijaniu mechanizmów dyplomatycznych. Postulowano włączenie ambasad i konsulatów państw członkowskich do działań dyplomatycznych na rzecz propagowania kultury europejskiej przy współpracy z instytutami kultury tychże.

Wykorzystanie w stosunkach międzynarodowych UE istniejących zasobów państw członkowskich było tyleż logiczne, co wskazywało na słabość instytucji unijnych. Biorąc pod uwagę konstytucyjną troskę państw członkowskich o partykularne interesy międzynarodowe, rozwiązanie to mogło być nieskuteczne. Pomocnym w tej sytuacji okazało się EUNIC, czyli ustanowione parę lat wcześniej stowarzyszenie instytutów kultury państw członkowskich, które przekształciło się w EUNIC Global i zbudowało Klastry współpracy (w obrębie instytutów) działające na rzecz propagowania kultury europejskiej. To właśnie Klastry EUNIC zaczęły odgrywać rolę czołowych partnerów Delegatur UE w państwach partnerskich, w związku z czym Delegatury mogły zainicjować cykliczne imprezy kulturalne promujące Europę, takie jak: „Europejski Dzień Języków” czy „Europejski Miesiąc Kultury”.

Na ukształtowanie opisanej struktury organizacyjnej, jak i ogłoszenie analizowanych strategii i agend miała niewątpliwie wpływ działalność polityczna Wysokich Przedstawicieli Unii do spraw zagranicznych i polityki bezpieczeństwa, choć z oczywistych względów nie była to ich działalność kluczowa. O ile aktywność Javiera Solany jako WP i zarazem sekretarza generalnego Rady UE sprowadzała się do wysyłania impulsów na rzecz działań zewnętrznych w kulturze oraz patronatu nad ratyfikowaniem przez UE Konwencji UNESCO z 2005 r., o tyle rola Catherine Ashton rosła jeśli chodzi o inicjaty- 
wy kulturalne w polityce zagranicznej. To właśnie za kadencji Aston ${ }^{4}$ powstało Preparatory Action, a Instytut Goethego wybił się na pozycję najważniejszego partnera WP i Delegatur UE. Dodatkowo wzrastała międzynarodowa rozpoznawalność EUNIC Global ${ }^{5}$ i Klastrów jako wykwalifikowanych konsorcjów współpracy, dysponujących wysokiej klasy menedżerami kultury oraz profesjonalnym zapleczem instytucjonalnym pozwalającym na inicjowanie spectrum europejskich działań. Status EUNIC wprost umożliwiał współpracę z wiodącymi instytucjami UE. Artykuł 2 Statutu określał EUNIC ,jako partnera Komisji Europejskiej i innych instytucji europejskich, w definiowaniu i wdrażaniu europejskiej polityki kulturalnej” oraz (art. 5),„w dzieleniu się najlepszymi praktykami i omawianiu wspólnych problemów" (Statut EUNIC, 2020).

Wyjątkowo aktywnym na polu kultury Wysokim Przedstawicielem okazała się włoska demokratka Frederica Mogherini ${ }^{6}$. Chętnie wypowiadała się na temat kultury, nie stroniła od spotkań ze środowiskami artystycznymi i udziału w specjalistycznych seminariach kulturalnych. Podczas konferencji prasowej, zwołanej w dniu 8 czerwca 2016 r. przez Komisję Europejską w celu skomentowania Strategii UE w dziedzinie międzynarodowych stosunków kulturalnych, Mogherini powiedziała: „Kultura musi być nieodłączną częścią naszej polityki zagranicznej. Jest potężnym narzędziem do budowania mostów pomiędzy ludźmi, zwłaszcza młodymi i do wzmocnienia wzajemnego zrozumienia. Może być również siłą napędową rozwoju gospodarczego i społecznego. Kiedy stajemy w obliczu wspólnych wyzwań, kultura może pomóc nam wszystkim, w Europie, w Afryce, na Bliskim Wschodzie, w Azji, połączyć wysiłki, by zwalczać radykalizację postaw i budować sojusz cywilizacji na przekór tym, którzy próbują nas poróżnić. To dlatego dyplomacja kulturalna musi przesuwać się na centralną pozycję naszych stosunków z dzisiejszym światem" (KE: Komunikat prasowy, 2016). To ,pro-kulturowe” stanowisko Wysokiej Przedstawiciel dało się też wysłuchać z jej wystąpienia na Forum Kultury w Brukseli w dniu 10 kwietnia 2016 r. (Speech for the $H R / V P, 2016)$, kiedy mówiła o użyciu ,miękkiej siły” kultury i edukacji do budowania trwałych relacji z państwami trzecimi oraz „twardej siły” przemysłów kreatywnych dla pozyskiwania rynków zewnętrznych, budowania bezpieczeństwa gospodarczego i spójności społecznej. Ustanawiając 2018 rok „Europejskim Rokiem Dziedzictwa" uczyniła ochronę i promocję europejskiego dziedzictwa kulturowego kolejnym wiodącym tematem polityki zagranicznej UE. Powiedziała: „Odtworzenie i ochrona naszego dziedzictwa pokazuje szacunek dla różnych tożsamości, które składają się na Europę i jej sąsiednie regiony" (Speech for the HR/VP, 2016).

Komisja Europejska w komunikacie prasowym z dnia 23 maja 2017 r. (KE: A New Strategy, 2017) potwierdziła ważną rolę instytutów kultury państw członkowskich UE skupionych w sieci EUNIC w prowadzeniu relacji zewnętrznych UE. Podkreśliła

${ }^{4}$ Catherine Aston pełniła funkcję Wysokiego Przedstawiciela Unii do spraw zagranicznych i polityki bezpieczeństwa w latach 2008-2014.

5 Pierwsze EUNIC powstają w 2006 r. Pierwszym szefem EUNIC został Sir David Green, dyrektor generalny British Council. 21 lutego 2007 r. podczas oficjalnego otwarcia EUNIC w Brukseli, stanowisko Austrii w sprawie EUNIC przedstawił Emil Brix, Dyrektor generalny ds. zewnętrznych stosunków kulturalnych w austriackim MZS. Biuro EUNIC Global zostaje otwarte w Brukseli w 2012 r.

${ }^{6}$ Federica Mogherini pełniła funkcję Wysokiego Przedstawiciela Unii do spraw zagranicznych i polityki bezpieczeństwa w latach 2014-2020. 
kluczową rolę informacyjną internetowej Platformy relacji kulturalnych UE (Resources / Publications related to ICR, Cultural relations platform) monitorującej działania kulturalne w obszarze działań zewnętrznych UE. Komunikat prasowy informował też o efektywności akcji kulturalnych prowadzonych przez UE wraz z UNESCO w zakresie ochrony dziedzictwa kulturowego, o czym wspominała Mogherini. Potwierdzono udzielenie dotacji UE na ochronę zabytków środkowoafrykańskiego miasta Timbukt (Mali), dziedzictwa muzycznego Republiki Vanuatu (Oceania), Mozambiku i Nigerii. Komisja Europejska planowała dopuszczenie Tunezji do udziału w kolejnej edycji programu „Kreatywna Europa”, jak również współfinansowanie Pawilonu Tunezyjskiego na Biennale w Wenecji. Unia Europejska była obecna jako gość honorowy na Międzynarodowych Targach Książki w Indiach w 2018 r.

Dzięki Mogherini ochrona i promocja kultury europejskiej weszła w skład zadań Globalnej strategii na rzecz polityki zagranicznej i bezpieczeństwa Unii Europejskiej, ogłoszonej przez WP 28 czerwca 2017 r. (Globalna strategia, 2017). Globalna strategia posiada 5 istotnych celów: bezpieczeństwo Unii; sąsiedztwo - inwestowanie w odporność państw i społeczeństw leżących na wschód i południe od UE; zintegrowane podejście do sytuacji konfliktowych (wojna i kryzys); wspieranie stabilnych porządków regionalnych opartych na współpracy oraz skuteczne globalne rządzenie w XXI wieku. Sprawy kultury zostały umieszczone w priorytecie drugim i zdefiniowane jako metoda na wzmacnianie odporności obywatelskiej społeczeństw sąsiadujących z UE. Kultura miała, zgodnie z literą tekstu, służyć „,pogłębianiu stosunków ze społeczeństwem obywatelskim" (ibidem), budowaniu dialogu oraz poczucia bezpieczeństwa w ramach ustalonych zasad praworządności, w tym poprzez przestrzeganie praw człowieka. Obok instytucji kulturalnych podobne zadanie w Globalnej strategii otrzymały wspólnoty religijne, partnerzy społeczni oraz obrońcy praw człowieka. Działania kulturalne, edukacja i nauka, miały zgodnie z założeniami dokumentu, uczyć pluralizmu (kulturowego, językowego) oraz wzajemnego szacunku społeczeństw.

Wybrany na Wysokiego Przedstawiciela Unii do spraw polityki zagranicznej i bezpieczeństwa w 2019 r. Josep Borell z partii Europejskich Socjalistów kontynuuje dobre praktyki swoich poprzedniczek. Podczas przesłuchania na stanowisko WP przez Komisję do spraw zagranicznych, na pytanie, jaką rolę UE może odegrać w tworzeniu globalnego bezpieczeństwa, odpowiedział: „Potrzebujemy wspólnej kultury strategicznej i empatii, aby zrozumieć różne punkty widzenia" (Przestuchanie przez Komisję, 2019). Wydaje się, że pochwała ,jedności w różnorodności” zagości na stałe w działaniach Borella. Wraz z Maryią Gabriel, Komisarz ds. Innowacji, badań naukowych, kultury, edukacji i młodzieży obrali kurs wyznaczony przez priorytety omówionych tu dokumentów, rozwijając program „Europejskich Stolic Kultury”, projekt pilotażowy „Europejskich Domów Kultury” oraz testując innowacyjne modele i praktyki współpracy w krajach partnerskich.

\section{ESDZ i Delegatury UE a polityka kulturalna}

Trzecim ogniwem w podziale kompetencji UE w zakresie kulturalnych relacji zewnętrznych, oprócz WP i Komisji Europejskiej, jest z pewnością Europejska Służ- 
ba Działań Zewnętrznych (ESDZ), stanowiąca namiastkę przyszłej służby dyplomatycznej i posiadająca istotny wpływ na działalność Delegatur UE w państwach partnerskich.

Warto przypomnieć, że Wspólna Polityka Zagraniczna i Bezpieczeństwa UE (WPZiB) została określona w traktacie z Lizbony (Tytuł V TUE), nie jest objęta jednolitym reżimem wspólnotowym i jest prowadzona w następujących dziedzinach (art. 21-22): ochrona wartości i interesów UE, wzmacnianie demokracji, państwa prawa i praw człowieka w świecie, utrzymanie pokoju, zapobieganie konfliktom i wzmacnianie bezpieczeństwa, wspieranie także trwałego rozwoju gospodarczo-społecznego; zachęcanie państw do integracji w ramach gospodarki światowej, niesienie pomocy państwom które ucierpiały w z powodu katastrof lub klęsk żywiołowych. Wspólna polityka zagraniczna i bezpieczeństwa należy do kompetencji szczególnych (koordynacyjnych) UE i posiada specjalny status. WPZiB ma charakter międzyrządowy i ponadnarodowy ze wskazaniem na międzyrządowość. Jest prowadzona przez Wysokiego Przedstawiciela Unii do spraw zagranicznych i polityki bezpieczeństwa, Radę Europejską oraz Radę UE, które działają jednomyślnie (chyba, że traktaty stanowią inaczej) oraz przez Wysokiego Przedstawiciela UE wspólnie z Komisją Europejską. Rada Europejska opracowuje cele strategiczne, natomiast Rada UE podejmuje decyzje. Państwa członkowskie zgłaszają swoje uwagi dotyczące polityki zagranicznej UE podczas posiedzeń Rady UE. W ten sposób polityka zagraniczna i bezpieczeństwa ma charakter międzyrządowy. Wysoki Przedstawiciel Unii wykonuje potrójny mandat obejmujący: prowadzenie wspólnej polityki zagranicznej i bezpieczeństwa, przewodniczenie Radzie do Spraw Zagranicznych i sprawowanie funkcji wiceprzewodniczącego Komisji. W tym względzie polityka zagraniczna ma charakter ponadnarodowy. Z upoważnienia RUE i w porozumieniu z ministerstwami spraw zagranicznych państw członkowskich WP opracowuje, prowadzi i realizuje WPZiB; koordynuje w RUE i KE wszystkie działania zewnętrzne UE oraz czuwa nad ich spójnością; reprezentuje UE na arenie międzynarodowej. W ramach WPZiB wykluczone są akty ustawodawcze. PE i KE odgrywają w WPZiB ograniczoną rolę, zaś TSUE zasadniczo nie ma w niej Żadnych kompetencji.

WPZIB posiada wiele ograniczeń (Węc, 2016, s. 252-253). Do jednych z nich należy fakt słabych kompetencji ustawodawczych KE i PE, co skutkuje w dziedzinie kultury tym, że jej priorytety wyznaczają dokumenty niewiążące (opinie, rezolucje, konkluzje), a co oznacza brak solidnych podstaw do prowadzenia unijnej dyplomacji kulturalnej. Inicjatywy WP mogą być blokowane przez państwa członkowskie. Przy podejmowaniu decyzji w trybie jednomyślnym każde państwo członkowskie ma możliwość konstruktywnego wstrzymania się od głosu, zaś podczas głosowania w trybie większości kwalifikowanej może powołać się na interes narodowy. Fakt utworzenia stanowiska WP oraz administracji ESDZ nie narusza odpowiedzialności państw członkowskich UE za kształtowanie własnej polityki zagranicznej, powoływania i odwoływania swoich służb dyplomatycznych oraz budowania indywidualnych relacji wobec państw trzecich. Może to oznaczać w praktyce, iż - mimo konsensusu państw członkowskich co do celów Globalnej strategii z 2016 r. - występują pomiędzy państwami członkowskimi rozbieżności co do celów partykularnych i regionalnych, a to również odbija się na promowaniu wspólnych wartości kulturowych. 
W nawiązaniu do art. 27 ust. 3 TUE, Rada UE zdefiniowała strukturę wewnętrzną Służby wydając Decyzję Rady z dnia 26 lipca 2010 r. określająca organizację i zasady funkcjonowania Europejskiej Służby Działań Zewnętrznych (Decyzja Rady, 2010) W skrócie, działanie ESDZ polega na wspieraniu wszystkich instytucji UE odpowiedzialnych za politykę zagraniczną oraz dbałości o jej spójność. Decyzja ustaliła, że za działanie ESDZ bezpośrednio odpowiada WP, strukturalnie jest ona podzielona na dyrekcje zarządzające (Rewizorski, Przybylska-Maszner, 2012). Skład ESDZ stanowią urzędnicy departamentów SG RUE, urzędnicy KE oraz personel MSZ państw członkowskich.

Art. 5 ust. 7-10 Decyzji reguluje działalność Delegatur UE. Delegatury mają ułatwiać kontakty instytucji Unii Europejskiej z państwami trzecimi lub organizacjami międzynarodowymi, przy których są akredytowane; szef delegatury reprezentuje Unię jako całość w państwie trzecim lub przed organizacją międzynarodową, przy której jest akredytowany. Personel Delegatur musi się kierować interesem Unii Europejskiej niezależnie od ewentualnych nacisków, jakie mogą być na niego wywierane przez reprezentantów państw członkowskich. Na wniosek państw członkowskich Delegatury wspierają państwa członkowskie w ich zadaniach, w tym w zakresie opieki konsularnej nad obywatelami UE (Nitszke, 2019). O Delegaturach mówi też TFUE. W świetle art. 221 ust. 1-2 TFUE „Delegatury Unii w państwach trzecich i przy organizacjach międzynarodowych zapewniają reprezentację Unii" (Wersje skonsolidowane TFUE, 2012) oraz „Delegatury Unii podlegają Wysokiemu Przedstawicielowi Unii ds. polityki zagranicznej i bezpieczeństwa. Działają one w ścisłej współpracy z misjami dyplomatycznymi i konsularnymi Państw Członkowskich" (ibidem).

Kulturę w ramach struktur ESDZ wspiera odpowiedni sektor administracji, monitorując aktualne wydarzenia związane z reprezentacją Komisji w sprawach kultury (np. opieka nad Remembrance Day czy projektem pilotażowym „Europejskie Domy Kultury"). Jednakże trzeba stwierdzić, że kultura stanowi jeden z najsłabszych obszarów kompetencji Wysokiego Przedstawiciela z racji chociażby tego, że nie jest traktatowo objęta zakresem jego obowiązków. Wiele zależy zatem od ambicji politycznych WP, nacisków europejskich środowisk artystycznych czy postrzegania kultury $\mathrm{w}$ aspekcie globalnych interesów UE. Przeanalizowane w niniejszym artykule dokumenty unijne z omawianego zakresu tematycznego wskazują na fakt starań decydentów politycznych o wprowadzenie kultury w obieg zewnętrzny Unii. Realizowana jest więc $\mathrm{w}$ tym przypadku funkcja programująco-inicjatywna i reprezentacyjna WP (Dubowski, 2017). Delegatury UE, jak i ESDZ, zgodnie z przepisami, są w stanie prowadzić działania w zakresie kultury pod warunkiem, że taką działalność zaleci im Wysoki Przedstawiciel. Pytanie więc, czy działają w tym obszarze?

Unia Europejska posiada ok 139 Delegatur w państwach poza UE. Panuje generalnie negatywna opinia o Delegaturach UE jakoby brakowało im zaangażowania w promocję kultury europejskiej jako zintegrowanego produktu czy wspólnego głosu europejskich narodów. Tradycyjnie utrzymują w pierwszej kolejności relacje partnerskie $\mathrm{z}$ ambasadami państw członkowskich $\mathrm{i}$ ich służbami konsularnymi, dopiero $\mathrm{w}$ drugiej kolejności zajmują się współpracą z instytutami kultury państw członkowskich UE jako swoimi partnerami (Research for Cult Committee, 2016). Nawet jeśli Delegatury proponowały w wielu państwach cykliczne wydarzenia promujące Europę (,Europej- 
ski Miesiąc Kultury”, „Europejski Dzień Języków”, „Noce Literatury Europejskiej”, festiwale filmowe UE) to stosowana metoda marketingowa nie odpowiadała paradygmatowi polityki kulturalnej UE ,jedność w różnorodności”. Oddając sporą przestrzeń do zagospodarowania ambasadom i konsulatom, pozwalały na prezentację odseparowanych i zindywidualizowanych wersji kultur narodów europejskich, zamiast manifestacji artystycznych będących symbolem integracji i wspólnego dziedzictwa kulturowego. Taki rodzaj prezentacji kultury europejskiej pogłębiał procesy fragmentacji kulturowej i dezintegracji Europy. Wydaje się, że ostatnimi czasy nastąpiła tu pewna zmiana na lepsze.

Jak wspominaliśmy, Delegatury zaczęły intensywniej współpracować z Klastrami EUNIC znajdującymi się na terytorium państw trzecich, co wpłynęło ożywczo na promocję kultury europejskiej w niektórych rejonach świata. Dnia 6 maja 2017 roku podczas prezydencji duńskiej w Radzie UE, podpisane zostało w Brukseli tzw. Porozumienie Administracyjne ${ }^{7}$ (Administrative arrangement, 2017) pomiędzy siecią EUNIC Global a ESDZ i Komisją Europejską. Porozumienie to określiło wspólne podstawy i cele współpracy. Potwierdziło chęć budowania nowego podejścia do działań zewnętrznych UE w kulturze, czemu miała służyć współpraca pomiędzy wyżej wymienionymi podmiotami, ze szczególnym naciskiem na EUNIC. Współpraca miała opierać na „geometrii zmiennej”, polegającej na tworzeniu różnych konstelacji współpracy. Ich kształt miał być uzależniony od interesów regionalnych poszczególnych stron oraz celów ich działalności na danym obszarze. Porozumienie zmierzało do ustanawiania wspólnych projektów finansowanych z dobrowolnych składek poszczególnych partnerów (EUNIC, ESDZ, KE). Porozumienie nie przewidywało osobnego budżetu i nie gwarantowało środków finansowych ze strony ani ESDZ ani KE. Zasadniczo ustalono trzy priorytetowe obszary współpracy. Należały do nich: 1) promowanie kultury i dialogu międzykulturowego na rzecz pokojowych stosunków między społecznościami; 2) wspieranie kultury jako siły napędowej zrównoważonego rozwoju społecznego i gospodarczego; 3) wzmocnienie współpracy w zakresie dziedzictwa kulturowego.

Zintegrowanie działań Instytutów i Klastrów pozwoliło tym strukturom sieciowym przystępować do projektów dofinansowywanych np. z programu „Kreatywna Europa”. Poniżej przytoczono kilka przykładów kulturalnej współpracy międzyinstytucjonalnej UE ze swoimi strategicznymi partnerami w państwach trzecich. Jednym z pierwszym projektów przygotowanych z budżetu „Kreatywnej Europy” (2014-2015) był „EUNIC - Crossroads for Culture. Enhancing EU Member States Transnational and International Cooperation" (EUNIC - Crossroads for culture, 2014). Jego celem było wzmocnienie wewnętrznej współpracy sieci instytutów kultury w 90 regionach świata. W latach 2016-2019 Delegatura UE w Tunisie wraz z lokalnym Klastrem EUNIC (pod kierunkiem British Council) oraz tunezyjskim ministerstwem kultury prowadziło projekt kulturalny „Tfanen-Tunisie Creative” skierowany na poprawę dialogu międzykulturowego. W latach 2017-2020 realizowano na Ukrainie projekt „Kulturalne Mosty" w partnerstwie EUNIC Klaster w Kijowie oraz Centrum Czeskie HQ (Ukra-

${ }^{7}$ Porozumienie uroczyście podpisali: prezes EUNIC Michael Metz oraz ze strony ESDZ: Lotte Knudsen, ze strony Dyrekcji Generalnej do spraw Edukacji, Młodzieży, Sportu i Kultury jeden z dyrektorów Wykonawczych, Jens Nymand-Christensen. 
ine Culture Bridges, 2017). W 2020 r. w Czechach realizowano projekt kulturalny o nazwie „Idea's Yard - Talking about Europe”, którego celem była szeroka dyskusja na temat idei Europy. Projekt prowadziło EUNIC na terytorium Czeskiej Republiki, w skład którego wchodziły: Goethe-Institut, Austriackie Forum Kultury, British Council, Ambasada Niderlandów, Instytut Włoski, Instytut Polski oraz szereg partnerskich instytucji czeskich (Idea'a Yard, 2020).

Uchodząca za aktywną Delegatura UE w Waszyngtonie D.C. regularnie promuje kulturę europejską poprzez „Europejski Miesiąc Kultury”. Raz do roku w maju trwa przegląd kultur państw członkowskich UE dzięki wsparciu ambasad i konsulatów państw członkowskich obecnych w Waszyngtonie oraz dzięki Klastrowi „Washington DC”, prowadzonemu pod auspicjami Ambasady Czeskiej w USA. Oferowane są różne programy kulturalne: występy muzyczne, taneczne, wykłady, pokazy filmowe, wystawy, konferencje i warsztaty. Większość wydarzeń jest bezpłatna. „Europejski Miesiąc Kultury” daje odwiedzającym możliwość zapoznania się z kulturami Unii Europejskiej, wzmacniając jednocześnie więzi między misjami UE a wiodącymi amerykańskimi instytucjami kultury. Dodatkowo w tym samym miesiącu ambasady państw członkowskich UE włączają się z inicjatywą „Dzień Domu Otwartego UE”. Każde z 28 państw członkowskich Unii Europejskiej otwiera swoją ambasadę lub miejsce zamieszkania ambasadora dla zwiedzających. Widownia poznaje artystyczne i kulinarne tradycje Europy.

Dzięki Porozumieniu z 2017 r. w dniu 17 stycznia 2020 r. EUNIC Global wraz z ESDZ wybrał pięć projektów pilotażowych w ramach szerszego projektu budowania „Europejskich Domów Kultury”. Projekty były realizowane w okresie od marca do października 2020 r., na co przeznaczono 50 tys. euro w całości ${ }^{8}$. Do konkursu stanęły Instytuty EUNIC wraz z delegacjami UE oraz lokalnymi partnerami (30 EUNIC, 39 Delegacji, 121 partnerów lokalnych). Ostatecznie eksperci wybrali 10 z 42 zgłoszonych projektów (European 'Houses' of Culture', 2019). Należały do nich m.in.: 1) Benin: Urban Cult Lab’Africa', 2) El Salvador, Guatemala \& Honduras: “Triángu-

${ }^{8}$ Przewidywano 2 lata na projekty Europejskich Domów Kultury, na co przewidywano 833 tys. euro przekazanych na granty na wytypowane projekty. Desygnowana kwota pochodziła ze środków Komisji Europejskiej (90\%) oraz EUNIC Global (10\%). Więcej patrz: https://www.eunicglobal.eu/european-houses-of-culture, 24.03.2020.

${ }_{9}$ Projekt Urban Cult Lab'Afryka polegał na rozwoju kultur miejskich poprzez współpracę środowisk artystycznych rożnych miast afrykańskich pochodzących z takich państw jak: Benin, Burkina Faso, Wybrzeże Kości Słoniowej, Mali, Mauretania i Togo, we współpracy z operatorami europejskimi. Projekt El Salvador, Guatemala \& Honduras: „Triángulo Teatro” (Central American European Theatre Circuit) maił polegać na produkcji przedstawień teatralnych w Salwadorze, Gwatemali oraz Hondurasie, inspirowanych dramaturgią europejską oraz amerykańską; pokazy przedstawień i tournée teatrów po Ameryce Łacińskiej, z dbałością o rozwój publiczności. Trzeci projekt: Mongolia: Nogoonbaatar - International Eco Art Festival to pierwszy w Mongolii festiwal ekologiczny pokazany w Ułan Bator, jednym z najbardziej zanieczyszczonych miast świata. Czwarty projekt: Sri Lanka: Colomboscope - On Language and Multitudinal Belonging to budowanie platformy dla lokalnych artystów i europejskich producentów, którzy wspólnie pracowali nad kwestiami kultury, języka, przynależności etniczno-religijnej w czterech różnych częściach Sri Lanki. Ostatni projekt The Grid miał za zadanie zbudować globalną sieć artystów i technologów, dzięki zasobom technicznym Doliny Krzemowej. Celem projektu było sprawdzenie, jak myślenie artystyczne wpływa na technologię czy twórcy humanizują technikę. https://www.eunicglobal.eu/news/european-houses-of-culture-10-ideas-selected, 8 11.2020. 
lo Teatro" (Central American European Theatre Circuit), 3) Mongolia: Nogoonbaatar - International Eco Art Festival, 4) Sri Lanka: Colomboscope - On Language and Multitudinal Belonging oraz 5) amerykański projekt, The Grid, wykorzystujący nowoczesne technologie Doliny Krzemowej.

\section{Zakończenie}

Wspólna Polityka Zagraniczna i Bezpieczeństwa realizuje ogólne założenia relacji zewnętrznych Unii Europejskiej w dziedzinie kultury. Dlatego jej priorytetami będą niezmiennie: ochrona wartości demokratycznych, pluralizm poglądów i form wyrazu kulturowego oraz utrzymanie pokoju i bezpieczeństwa, a także wzmacnianie przemysłów kreatywnych. Nie należy się spodziewać przełomów tematycznych w postaci np. otwierania uprzywilejowanych ścieżek promocji zintegrowanych form sztuki europejskiej czy spektakularnych inicjatyw kulturotwórczych. Obszarem wywalczonym przez WP dla polityki zagranicznej UE jest ochrona dziedzictwa kulturowego. Niewątpliwie relacje zewnętrzne Unii w kulturze mają charakter rozwojowy i zajmują coraz wyższą pozycję w hierarchii działań WP. Na to, aby mogły sięgnąć formy bardziej zaawansowanej, dojrzałej czy - jak powiedziała Mogherini „centralnej” - potrzeba w zasadzie modyfikacji przepisów. Zgodnie z traktatami i aktami prawnymi UE sektor kultury nie wiedzie prymu w polityce zagranicznej prowadzonej ani przez WP, ani ESDZ, ani Delegatury, ani Komisję. Jak próbowaliśmy wykazać, doceniana jest oczywiście rola soft power w unijnych stosunkach dyplomatycznych i z pewnością będzie rozwijana. Kultura jest na trwale włączona do polityk unijnych, programów i instrumentów pomocowych UE i może się kształtować samoistnie na wielu płaszczyznach. Kwestią kluczową wydaje się skorzystanie przez WP z katalogu swoich funkcji (np. zarządczych i koordynacyjnych), pozwalających na większe oddziaływanie na Radę UE czy podległą mu Służbę. Również kwestią zasadniczą jest zdolność Delegatur UE do prowadzenia bardziej zaawansowanych form prezentacji kultur europejskich w różnych rejonach świata, czyli prezentacji Europy jako zróżnicowanej wewnętrznie całości, a nie jako kalejdoskopu osobnych kultur narodowych. Zmiana paradygmatu w brandingu politycznym: z postrzegania Europy jako zbioru kultur narodowych na odczytywanie jej w kontekście wielości i wielokulturowości mogłoby być rozwiązaniem adekwatnym zarówno dla współczesnych czasów, jak i osiągniętego etapu rozwojowego Unii oraz poczucia tożsamości kulturowej Europejczyków. Jest to trudne czy wręcz niemożliwe do realizacji przynajmniej z trzech powodów. Po pierwsze, Delegatury UE nie posiadają osobnych kompetencji i uprawnień w dziedzinie kultury, a brak instruktażu ze strony WP w tym względzie skutkuje paraliżem form aktywności. Po drugie, Delegatury UE - współdziałając z ambasadami i konsulatami państw członkowskich, które nie chcą być związane decyzjami unijnymi w zakresie polityki zagranicznej - nie dysponują instrumentami dyscyplinującymi partnerów. Pozostaje ewentualnie proces negocjacji wspólnych interesów. Po trzecie, nie do końca wiadomo, jak prezentować kulturę europejską en bloc, odsłaniając jednocześnie jej zróżnicowanie narodowe, etniczne, językowe, literackie i artystyczne. Omówione dokumenty unijne nie poświęcały uwagi zagadnieniom esencjonalnym. Oprócz wykładni aksjonormatywnej, nie 
ma w nich dyskusji o nazwijmy to „europejskości” kultur narodowych, wspólnych trendach, wybitności dzieł europejskich czy ich funkcji społecznej. Właśnie z powodu deficytu głębszych przesłań ideowych na poziomie choćby uzupełniających do aktów prawnych prac eksperckich kwestia, jak prezentować światu kulturę europejską pozostaje enigmatyczna, a mechanizmy polityczne są w tym zakresie słabe.

Badacze uważają, że dyplomacja kulturalna UE albo promuje Unię jako „nowoczesną i atrakcyjną lokację dla edukacji, nauki, badań i profesjonalnego rozwoju" (Higgott, 2020, s. 27), albo jako „potęgę normatywną, zwłaszcza w kontekście popierania różnorodności kulturowej, która opiera się na zagwarantowaniu praw człowieka i poszanowaniu wolności" (Rynejska-Kiełdanowicz, Ratajczak, 2019, s. 119) albo jako „próbującą konkurować z polityką kulturalną państw członkowskich zamiast ją uzupełniać" (Fisher, 2014, s. 28). Polityce zagranicznej UE w sektorze kultury brakuje spójnego modelu. Być może nadchodzi moment jego poszukiwania. Biorąc pod uwagę wysiłek poczyniony na rzecz ukształtowania priorytetów tejże polityki (Globalna strategia, 2016) oraz współpracę instytucji unijnych z organizacjami pozarządowymi (EUNIC), przyszłością relacji zewnętrznych UE w kulturze są rozwiązania oddolne wypracowane w procesie dalszej ewolucji konceptów społeczno-kulturowych.

\section{Bibliografia}

\section{Dokumenty:}

Konwencja UNESCO $w$ sprawie ochrony i promowania różnorodności i form wyrazu kulturowego, Paryż 20.10.2005, Dz. Urz. WE, nr 215, poz. 1584 i 1595.

Decyzja nr 1983/2006/WE Parlamentu Europejskiego i Rady z dnia 18 grudnia 2006 r. w sprawie Europejskiego Roku Dialogu Międzykulturowego (2008), Dz. Urz. UE, L 412/44, 20.12.2006.

KE: Komunikat dotyczacy Europejskiej agendy ds. kultury w dobie globalizacji, Bruksela 10.05.2007, KOM (2007) 242 wersja ostateczna.

KE: Komunikat Komisji do Parlamentu Europejskiego, Rady, Europejskiego Komitetu Ekonomiczno-Społecznego oraz Komitetu Regionów, dotyczacy Europejskiej agendy kultury $w$ dobie globalizacji świata, Bruksela, dnia 10.5.2007 KOM (2007) 242 wersja ostateczna.

Rezolucja Rady z dnia 16 listopada 2007 r. dotyczaca europejskiego planu działań na rzecz kultury, Dz. Urz. UE C 287/1, 29.11.2007.

Opinia Komitetu Regionów Europejska agenda kultury w dobie globalizacji świata, Dz. Urz. UE C 53/05, 6.02.2008.

PE: Rezolucja Parlamentu Europejskiego z dnia 10 kwietnia 2008 r. w sprawie europejskiej agendy kultury w dobie globalizacji (2007/2211(INI)), Dz. Urz. UE C 247 E/32, 15.10.2009.

KE: Sprawozdanie Komisji do Parlamentu Europejskiego, Rady Europejskiej, Komitetu Ekonomiczno-Społecznego i Komitetu Regionów w sprawie wdrożenia Europejskiej Agendy Kultury, Bruksela, dnia 19.7.2010 KOM (2010)390 wersja ostateczna.

Decyzja Rady z dnia 26 lipca 2010 r. określająca organizację i zasady funkcjonowania Europejskiej Stużby Działań Zewnętrznych, Dz. Urz. UE L 201/30, 3.08. 2010.

Rezolucja Parlamentu Europejskiego z dnia 12 maja 2011 r. w sprawie kulturowego wymiaru działań zewnętrznych UE (2010/2161 INI).

Wersje skonsolidowane Traktatu o Unii Europejskiej i Traktatu o Funkcjonowaniu Unii Europejskiej, Dz. Urz. UE, C 326/47 z 26 października 2012. 
Rozporządzenie Parlamentu Europejskiego i Rady (UE) nr 1295/2013 z dnia 11 grudnia 2013 r. ustanawiajace program „Kreatywna Europa” (2014-2020) i uchylające decyzje nr 1718/2006/ WE, nr 1855/2006/WE i nr 1041/2009/WE, Dz. Urz. UE L 347/221, 20.12.2013.

Preparatory Action, Culture in EU External Relations" Engaging the World: Towards Global Cultural Citizenship, European Union, Brussels 2014.

Rozporządzenie Parlamentu Europejskiego i Rady (UE) nr 234/2014 z dnia 11 marca 2014 r. ustanawiające Instrument Partnerstwa na rzecz Wspótpracy z Państwami Trzecimi.

Rozporządzenie Parlamentu Europejskiego i Rady (UE) nr 235/2014 z dnia 11 marca 2014 r. ustanawiajace instrument finansowy na rzecz wspierania demokracji i praw człowieka na świecie.

Rozporządzenie Parlamentu Europejskiego i Rady (UE) nr 230/2014 z dnia 11 marca 2014 r. ustanawiające Instrument na rzecz przyczyniania się do Stabilności i Pokoju.

KE: Komunikat prasowy. Dyplomacja kulturalna UE potrzebuje nowego impulsu - tak wynika $z$ raportu, Bruksela 10.06.2014, http://europa/eu/rapid/press-release_IP-14-651_pl.htm, 5.10.2017.

Konkluzje Rady z dnia 24 listopada 2015 r. w sprawie kultury w stosunkach zewnętrznych UE ze szczególnym uwzględnieniem kultury we wspótpracy na rzecz rozwoju, Dz. Urz. UE, C 417/06, 15.12.2015.

KE: Wysoki Przedstawiciel Unii do spraw zagranicznych i polityki bezpieczeństwa. Wspólny Komunikat do Parlamentu Europejskiego i Rady, w stronę strategii UE w dziedzinie międzynarodowych stosunków kulturalnych, JOIN (2016) 29 final. Bruksela, 8.06.2016.

KE: Komunikat prasowy, Nowa strategia ma zapewnić kulturze poczesne miejsce w stosunkach międzynarodowych UE, Bruksela, 8 czerwca 2016 r., IP/16/2074.

Konkluzje Rady z dnia 15 czerwca 2017 r. w sprawie strategicznego podejścia UE do międzynarodowych stosunków kulturalnych, Dz. Urz. UE, C 189/38, 15.05.2017.

Konkluzje Rady z dnia 23 maja 2017 r. w sprawie strategicznego podejścia UE do międzynarodowych stosunków kulturalnych, Dz. Urz. UE, C 189/8, 16.06.2017.

Globalna strategia na rzecz polityki zagranicznej i bezpieczeństwa Unii Europejskiej, Rada Unii Europejskiej, Bruksela 28.06.2017, 10715/16 LIMITE, CFSP/PESC 543, CSDP/PSDC 39.

Komunikat Komisji do Parlamentu Europejskiego, Rady, Europejskiego Komitetu Ekonomiczno-Społecznego i Komitetu Regionów, Bruksela, dnia 22.5.2018 r., COM (2018) 267 final.

KE: A new strategy to put culture at the heart of EU international relations, Brussels. 23 May 2017, http://europa.eu/rapid/press-release_MEMO-16-2075_en.html, 15.09.2018.

\section{Opracowania:}

Alabrudzińska E. (red.), (2016), Dyplomacja europejska wobec wyzwań XX i XXI wieku, Wyd. A. Marszałek, Torun.

Bartkowiak Ł. (2007), Relacje Unii Europejskiej z państwami Afryki, Karaibów i Pacyfiku, „Rocznik Integracji Europejskiej", nr 1, s. 94-124.

Bartkowiak Ł. (2008), Stosunki zewnętrzne Unii Europejskiej, Wyd. A. Marszałek, Toruń.

Bieczyński M. A. (2011), Prawne granice wolności twórczości artystycznej w zakresie sztuk wizualnych, Wolter Kluwer Polska, Warszawa.

Boniecka M. (2015), Cele, zasady i struktura wspólnej polityki zagranicznej i bezpieczeństwa Unii Europejskiej-próba oceny po zmianach w traktacie lizbońskim, „Usus Iuris” Wydział Prawa i Administracji, UAM, Poznań, nr 5, s. 41-56.

Carta C., Higgott R. (red.) (2020), Cultural Diplomacy in Europe. Between the Domestic and the International, Palgrave-Macmillan, London.

Dubowski T. (2017), Wysoki Przedstawiciel Unii do spraw zagranicznych i polityki bezpieczeństwa, Wyd. Temida 2, Białystok. 
Fisher R., (2007), Cultural Dimensions to the EU's External Policies, From Policy Statements to Practice and Potential, Boekman Foundation, Amsterdam.

Fisher R. (2014), United States of America. Country Report, in: Preparatory Action. Culture in the EU External Relations, red. Yudhishthir Raj Isar, EU, Brussels.

Higgott R. (2020), EU Cultural Diplomacy: A Contextual Analysis of Constrains and Opportunities, in: Cultural Diplomacy in Europe: Between the Domestic and the International, red. R. Higgott, C. Carta, Palgrave-Macmilan1, London, s. 9-41.

Isar R. Y. (2015), Culture in EU external relations': an idea whose time has come, "International Journal of Cultural Policy", no. 4, s. 494-508.

Langowska J. (2018), Dyplomacja kulturalna czy kulturowa - definiowanie kultury i jej roli na arenie międzynarodowej, „Zeszyty Naukowe Towarzystwa Doktorantów UJ, Nauki Humanistyczne", nr 2, s. 37-60.

Littoz-Monet A. (2012), Agenda Setting Diplomacy at the EU Level, "Journal of European Integration", no. 5, s. 505-522.

Michałowska G. (2020), UNESCO: sukcesy, porażki, wyzwania, Wydawnictwo Naukowe Scholar, Warszawa.

Nitszke A. (2019), Europejska Stużba Działań Zewnętrznych - Nowa jakość dyplomacji unijnej?, „Politeja”, nr 3, s. 257-269.

Ociepka B. (red.) (2008), Dyplomacja publiczna, Wydawnictwo Uniwersytetu Wrocławskiego, Wrocław.

Psychogioupolou E. (2014), The External Dimension of the EU Cultural Action and Free Trade. Exploring and Interface, "Legal Issue of Economic Integration", no. 1, s. 65-86.

Raport (2010), Wdrażanie Konwencji UNESCO z 2005 r. w Unii Europejskiej, Dyrekcja Generalna ds. polityk wewnętrznych Unii. Departament Polityczny B: Polityka strukturalna i Polityka Spójności. Kultura i Edukacja, Bruksela, Parlament Europejski.

Ratajski S. (2014), Niematerialne dziedzictwo kulturowe w świetle ochrony i promowania różnorodności form wyrazu kulturowego, „Ochrona zabytków”, nr 1, s. 5-18.

Research for Cult Committee - European Cultural Institutes abroad. Study (2016), Directorate General for Internal Policies. Policy Department B: Structural and Cohesion Policies, Culture and Education, EU.

Rewizorski M., Przybylska-Maszner B. (2012), System instytucjonalny Unii Europejskiej po traktacie z Lizbony. Aspekty polityczne i prawne, Difin, Warszawa.

Ryniejska-Kiełdanowicz M. (2015a), Rola dyplomacji publicznej w kreowaniu zewnętrznego obrazu Unii Europejskiej, „Przegląd Zachodni”, nr 2, s. 157-174.

Ryniejska-Kiełdanowicz M. (2015b), Dyplomacja kulturalna jako narzędzie miękkiej siły Unii Europejskiej, „Politeja”, nr 37, s. 143-160.

Ryniejska-Kiełdanowicz M. (2019), Dyplomacja publiczna Unii Europejskiej, Wydawnictwo Naukowe Scholar, Warszawa.

Wawrowska H. (2015), Kultura i dyplomacja kulturalna Unii Europejskiej na przyktadzie Programu ,,Kreatywna Europa”. Analiza politologiczna, „Rocznik Integracji Europejskiej”, nr 9, s. 551-565.

Węc J. J. (2016), Traktat lizboński. Polityczne aspekty reformy ustrojowej Unii Europejskiej w latach 2007-2015, Księgarnia Akademicka, Kraków.

Ziętek A. (2010), Międzynarodowe stosunki kulturalne, Poltext, Warszawa.

\section{Źródla internetowe:}

Pamiętnik Federici Morgherini, 26 kwiecień 2016 r., http://www.federicamogherini.net/my-speechat-the-european-culture-forum-2016-brussels/?lang=en, 14.06.2020. 
Przemówienie Federici Mogherini, 9 czerwiec 2016 r., Bruksela, https://www.youtube.com/wat$\mathrm{ch} ? \mathrm{v}=\mathrm{QY} 191 \mathrm{BPT} \mathrm{X} \mathrm{s}, 14.06 .2020$.

Przemówienie Federici Mogherini na forum ONZ, 21 wrzesień 2017 r. Nowy Jork https://www. youtube.com/watch? $=\mathrm{z} 4 \mathrm{jaBM} 3 \mathrm{~b} 50 \mathrm{~g}, 14.06 .2020$.

Speech for the HR/VP. Federica Mogherini at the Culture Forum in Brussels, Bruxelles 10.04.1016, ttps://eeas.europa.eu/headquarters/headQuarters-homepage/5164/speech-hrvp-federicamogherini-culture-forum-brussels_en, 1.10.2018.

https://www.cultureinexternalrelations.eu/, 12.02.2020.

Statut EUNIC, https://uploads ssl.webflow.com/580cd32ba6f74f8a0e214914/5c5db5d7cd394bdf03d 3078c_Statute\%20ENG\%20-\%20June\%202016\%20(Website)_new.pdf, 19.03.2020.

Resources / EU Policy Documents, https://www.cultureinexternalrelations.eu/category/resources/eupolicy-documents/, 6.06.2019.

Przestuchanie przez Komisje Spraw Zagranicznych kandydata na WP, https://www.europeaninterest.eu/article/josep-borrell-need-shared-strategic-culture-empathy-understand-differentpoints-view/, 4.10.2020.

KE: A new strategy to put culture at the heart of EU international relations, Brussels. 23 May 2917, http://europa.eu/rapid/press-release_MEMO-16-2075_en.html, 15.09.2018.

Administrative arrangement for activities to be developed by the European Union National Institutes for Culture (EUNIC) in partnership with the European Commission Services and the European External Action Service jointly referred to hereinafter as "the two Sides", https://eeas. europa.eu/sites/eeas/files/2017-05-16_admin_arrangement_eunic.pdf, 7.02.2020.

Ukraine Culture Bridges, https://www.eunicglobal.eu/projects/cultural-bridges, 19.03.2020.

"Ideas Yard: Talking about Europe" is a series of discussions on the future of Europe, https://www. eunicglobal.eu/projects/eunic-prague-ideas-yards-talking-about-europe, 19.03.2020.

European 'Houses' of Culture', https://www.eunicglobal.eu/news/european-houses-of-culture10-ideas-selected, 7.10.2020.

Gross J., Wilson N., Bull A. (2017), Towards cultural democracy: Promoting cultural capabilities for everyone, Report. King's College London, London, https://www.kcl.ac.uk/Cultural/-/Projects/Towards-cultural-democracy, 20.04.2020.

\section{Streszczenie}

Polityka zagraniczna UE w dziedzinie kultury jest stosunkowo nowym i mało zbadanym obszarem działalności UE. Jej funkcjonowanie określił traktat z Lizbony, nakładając nań kompetencje programująco-inicjatywne oraz reprezentacyjne Wysokiego Przedstawiciela Unii do spraw zagranicznych i bezpieczeństwa (WP), ESDZ oraz delegatur UE. Dyplomację kulturalną UE prowadzą również - na zasadzie partnerstwa z Unią - instytuty kultury państw członkowskich, zarejestrowane w Stowarzyszeniu Narodowych Instytutów Kultury Unii Europejskiej (EUNIC) oraz ich klastry regionalne. Artykuł ma za zadanie prześledzić w trybie analiz ewolucji priorytetów zawartych w relacjach zewnętrznych UE w dziedzinie kultury (a także analiz instytucjonalnych) oraz zweryfikować, czy instrumenty polityczne zastosowane wobec soft power UE są wystarczające dla efektywnego kształtowania wizerunku kulturowego Europy w świecie. Tezą niniejszego artykułu jest twierdzenie, że relacje zewnętrzne UE w sektorze kultury odznaczają się słabą polityką, dlatego nie mają szans osiągnąć fazy dojrzałości, tym samym tworzyć trwałych podstaw do cywilizacyjnego oddziaływania kultury europejskiej, rozumianej w sposób integracyjny, czyli jako realizacja paradygmatu ,jedności w różnorodności”.

Słowa kluczowe: Relacje zewnętrzne Unii Europejskiej, kultura, dyplomacja kulturalna, soft power 


\section{The European Union External Relations in the Field of Culture. Policy Weaknesses}

\section{Summary}

The EU's foreign policy in the field of culture is a relatively new and under-explored area of the EU activity. Its operation was defined by the Treaty of Lisbon, imposing on it programming and initiative and representation powers of the High Representative of the Union for Foreign Affairs and Security (HR), the EEAS and EU Delegations. The EU cultural diplomacy is also conducted - on a partnership basis with the European Union - by the institutes of culture of the member states registered in the Association of National Institutes of European Union (EUNIC) and their regional Clusters. The article aims to follow in the evolution analysis mode the priorities contained in the EU's external relations in the field of culture (as well as institutional analysis) and verify whether the political instruments applied to the EU 'soft power' are sufficient to effectively shape Europe's cultural image in the world. The thesis of this article is that EU external relations in the cultural sector are characterized by poor politics, and therefore have no chance of reaching the maturity phase, thus creating a solid basis for the civilizational impact of European culture, understood in an integrative way, i.e. as the implementation of the "unity in diversity" paradigm.

Key words: External Cultural relations of the European Union, Culture, diplomacy, soft power 